REVISTA ARA No5 5 VOlUME 5 . PrIMAVERA+VERÃo 2018 • GRUPO MUSEU/PATRIMÔNIO FAU-USP

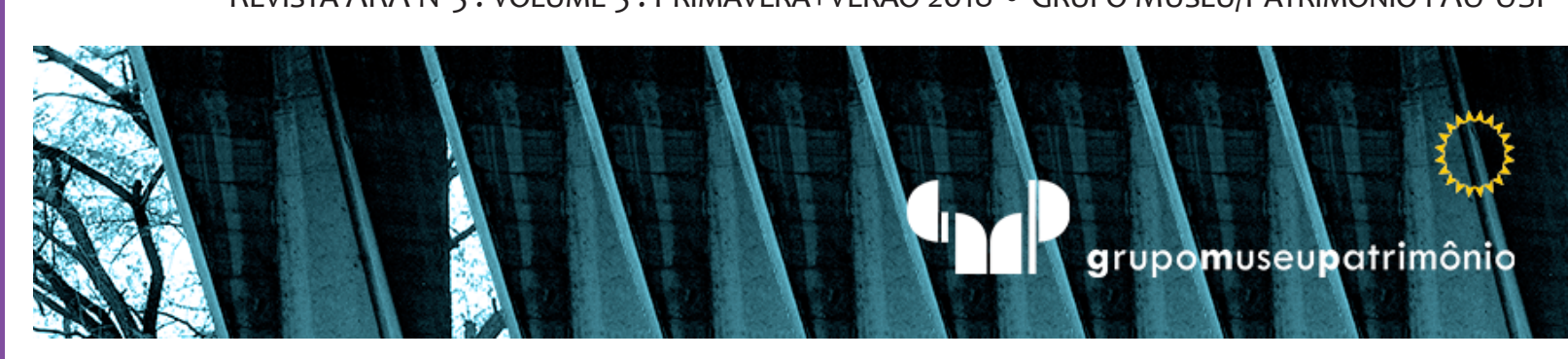

\title{
Paisagens Internas
}

Paisajes Internos

Interior Landscapes

Ilana Bessler

Universidade Presbiteriana Mackenzie, São Paulo, Brasil.

ilanabessler@gmail.com 


\section{Resumo}

No contexto das narrativas visuais proponho pensarmos imageticamente as possibilidades das fronteiras contemporâneas. $O$ espaço entre, o tempo entre. As fotografias remetem a espaços e tempos de construção de experiência memória. Momentos contemplativos onde nossas paisagens internas, já experimentadas, podem atuar ressignificando constantemente o presente. Essas fotos são resíduos de outros projetos (Habitado e Unlived Memories) e foram ressignficadas nessa edição. Mostrando também o lugar e a abries) e foram ressignficadas nessa outras prôncia de possibilides das imagens produidase como a fotografia se comporta quando é deslocada da sua significação primária. A abertura e o ganho de interpretações e experimentações que se pode ter a partir de uma foto é imenso. Esse ensaio é sobre tudo isso. Sobre tantas possibilidades que existem em uma foto. É sobre fazer fotografia e olhar fotografia.

Palavras-Chave: Fotografia. Narrativa imagética. Memória. Fronteira. Landscape.

\section{Resumen}

En el contexto de las narrativas visuales propongo pensar las imágenes de las fronteras contemporáneas. El espacio entre, el tiempo entre. Las fotografías remiten a espacios y tiempos de construcción de experiencia y memoria. Momentos contemplativos donde nuestros paisajes internos, ya experimentados, pueden actuar resignificando constantemente el presente. Estas fotos son residuos de otros proyectos (Habitado y Unlived Memories) y se han resignificado en esta edición. También muestra el lugar y el alcance de posibilidades de las imágenes producidas y cómo la fotografía se comporta cuando es desplazada de su significación primaria. La apertura y la ganancia de interpretaciones y ensayos que se pueden tener a partir de una foto es inmenso. Este ensayo es sobre todo eso. Sobre tantas posibilidades que existen en una foto. Es sobre hacer fotografía y mirar la fotografía.

Palavras-Clave: Fotografía. Narrativa imagética. La memoria. Frontera. Paisaje.

\section{Abstract}

In the context of visual narratives I propose to think imagetically the possibilities of contemporary borders. The space between, the time between. The photos refer to spaces and experience and memory construction times. Contemplative moments where our internal landscapes, already experienced, can act constantly giving new meaning to the present. These photos are the remains of other projects (Habitado and Unlived Memories) and have been re-signified in this projects (Habitado and Unlived Memories) and have been re-signified in thowing the place and scope of possibilities of the images produced and how photography behaves when it is displaced from its primary significance. It's immense the openness and gain of interpretations and experimentations that one can have. The essay is about all this. About so many possibilities that exist in a photo. It's about doing photography and looking at photography.

Keywords: Photography. Imagery narrative. Memory. Border. Landscape.

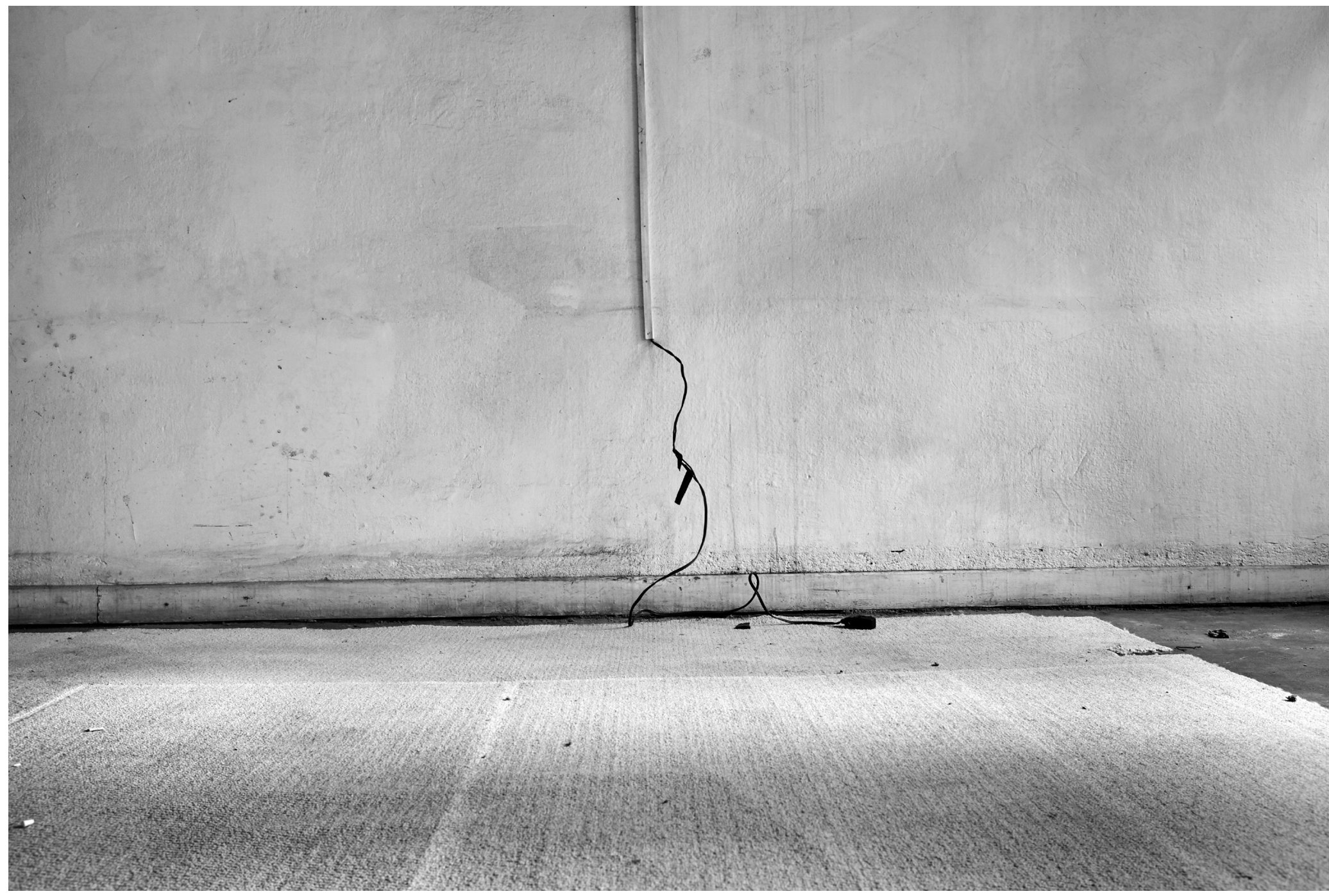

Figura 1: Vista Pro Mar \#1. Foto: Ilana Bessler 


\section{VISTA PRO MAR}

Figura 2: Vista Pro Mar \#2. Foto: Ilana Bessler

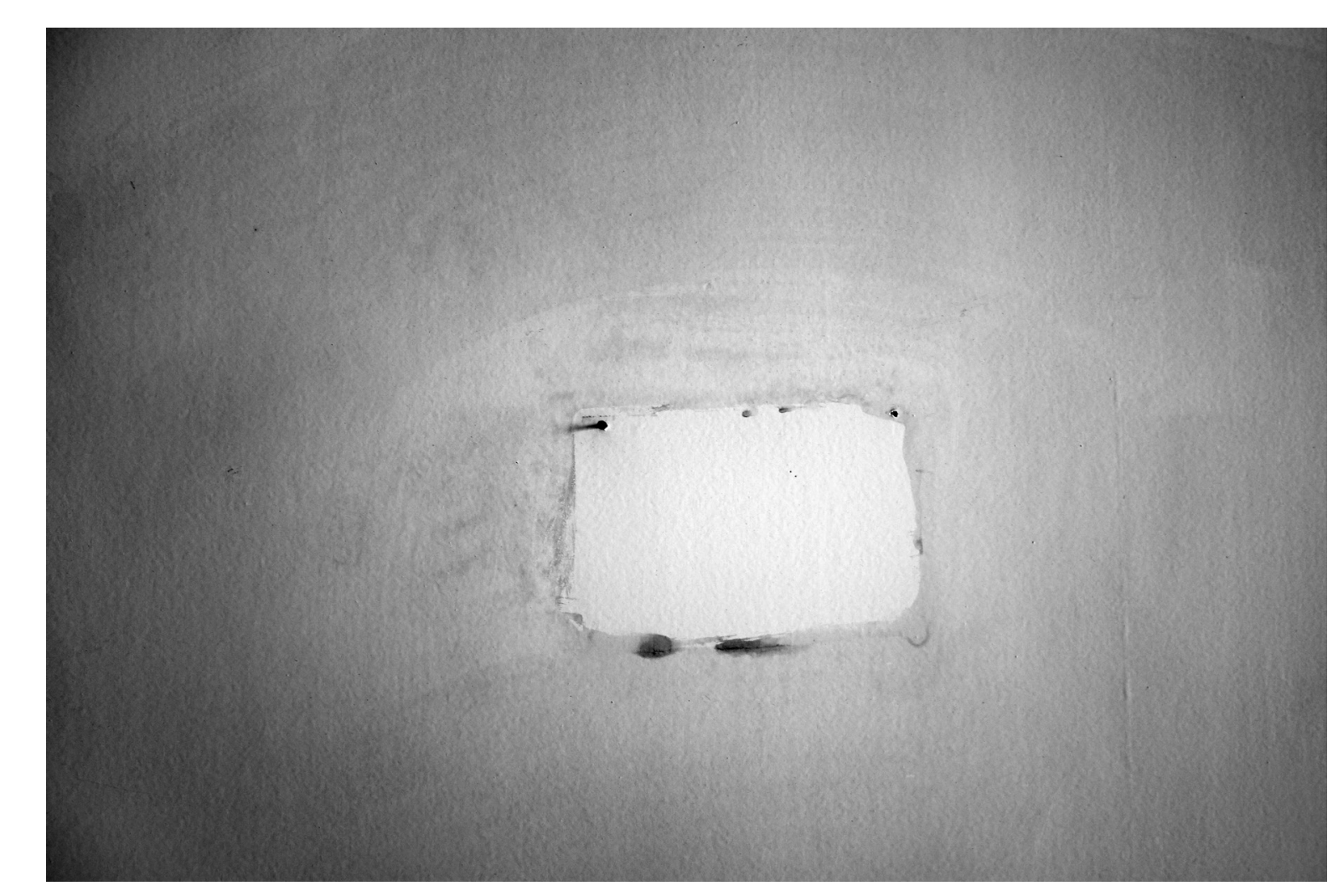

Figura 3: Vista Pro Mar \#3. Foto: llana Bessler 


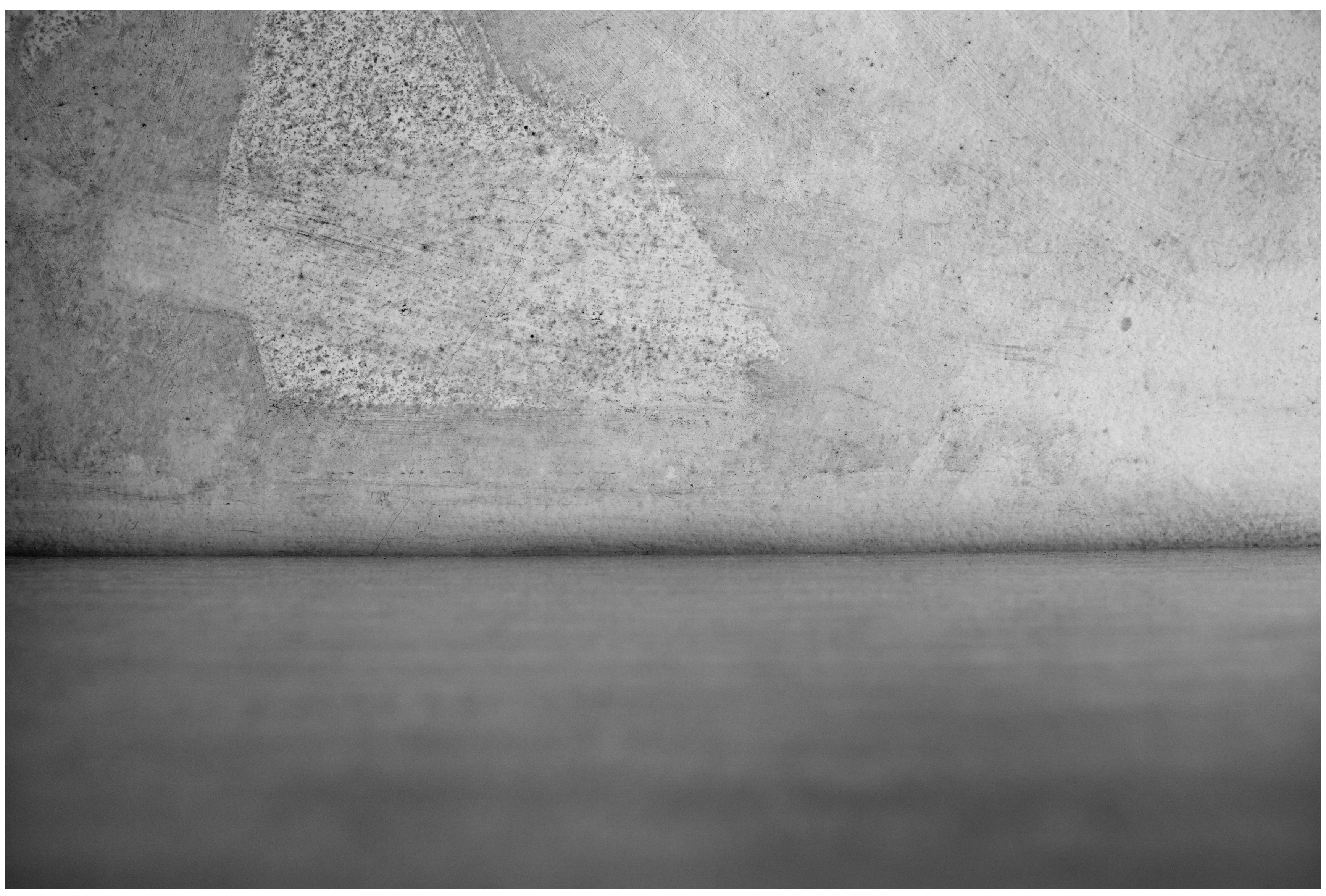




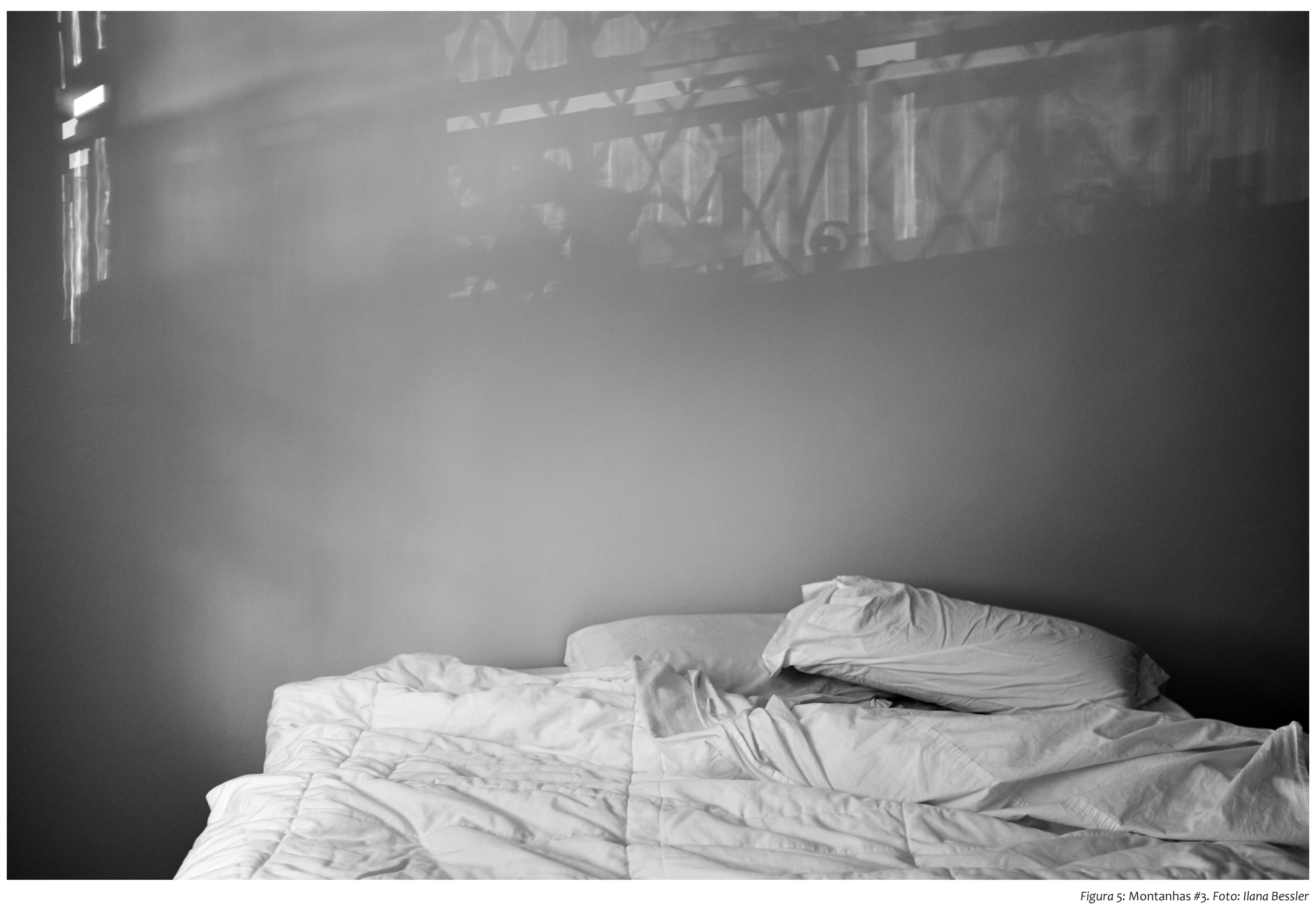


Figura 9: Jardim \#2. Foto: llana Bessler
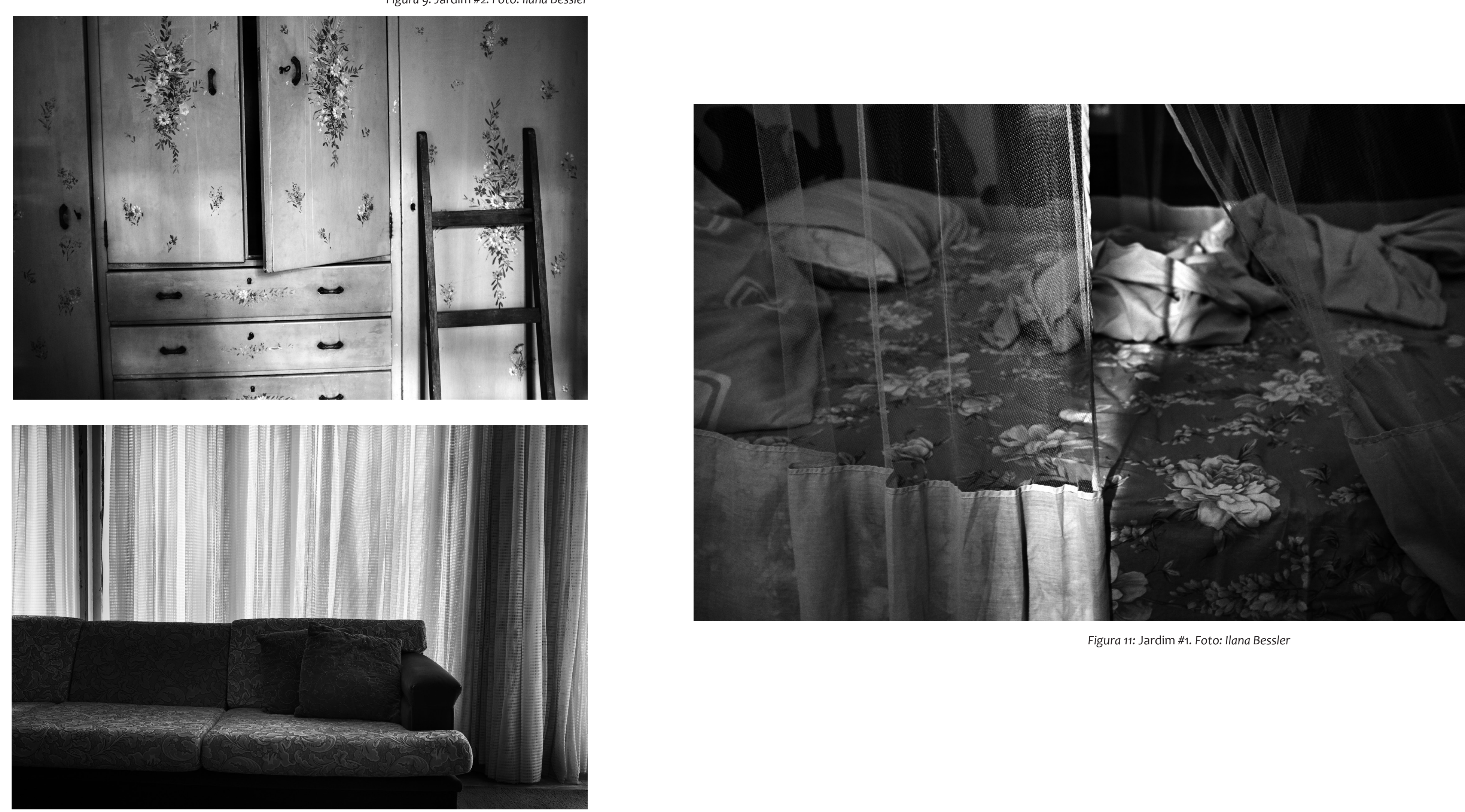

Figura 11: Jardim \#1. Foto: Ilana Bessler 


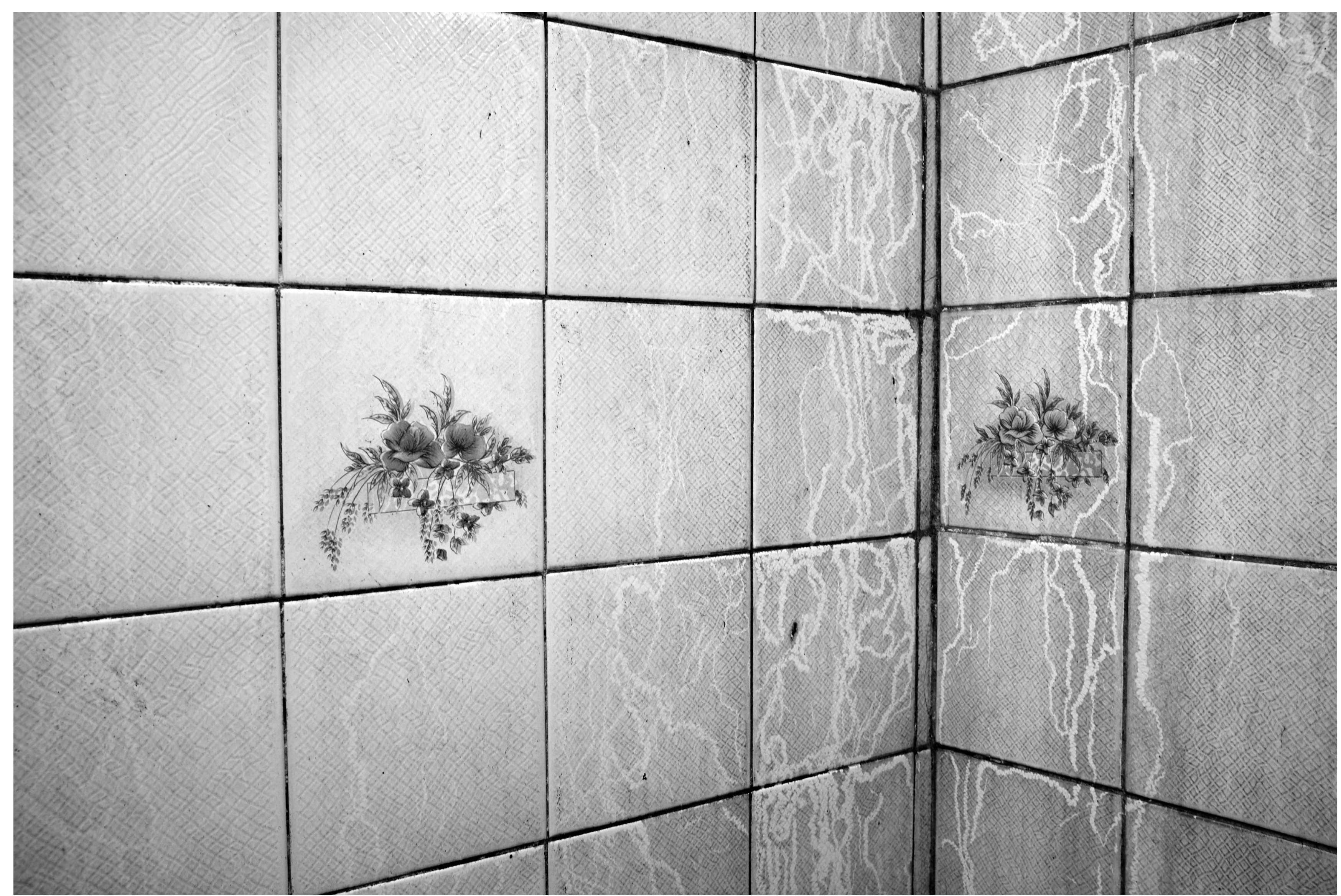




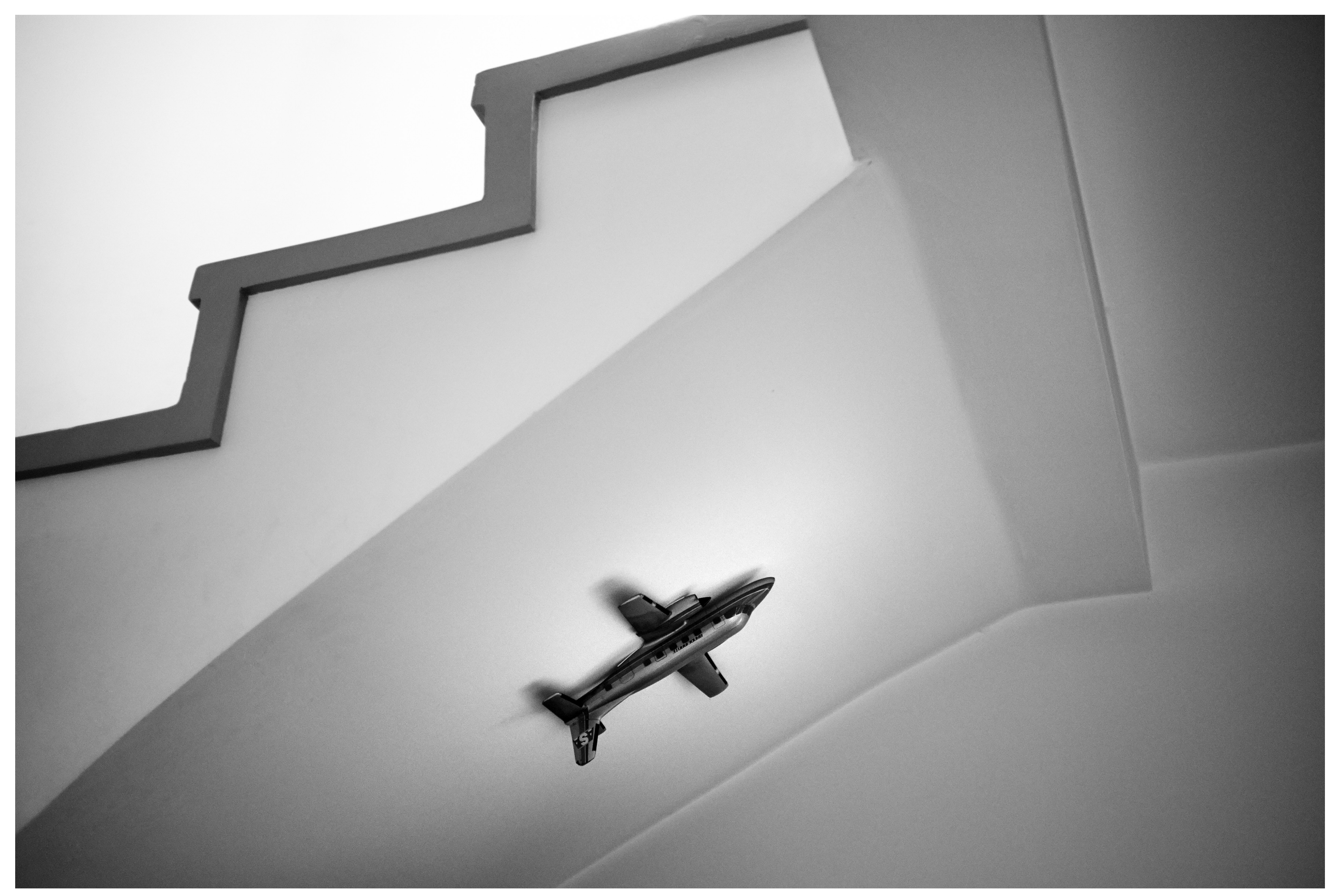


Figura 15: Observação do Céu \#2. Foto: llana Bessler

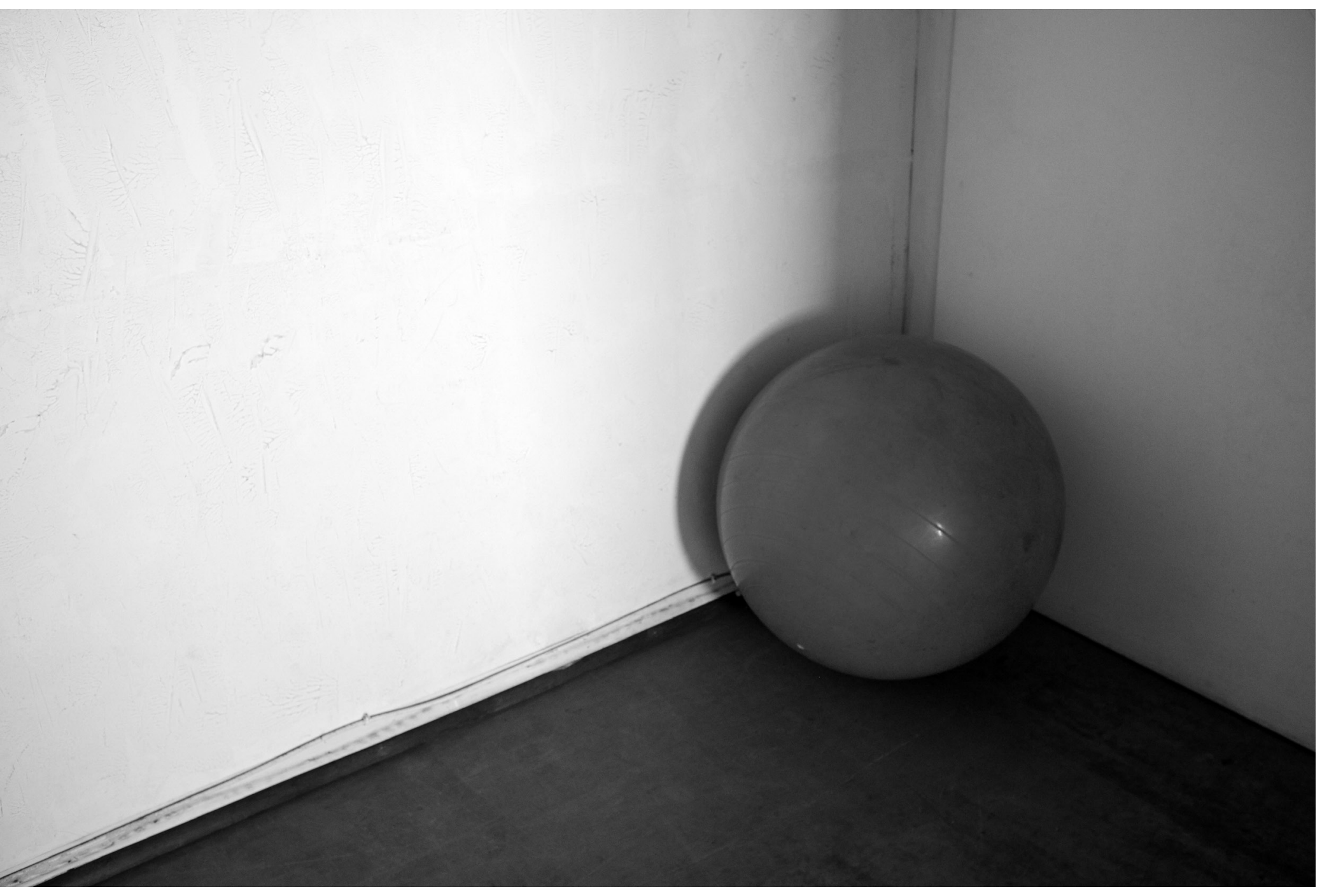

Figura 14: Observação do Céu \#3. Foto: llana Bessler
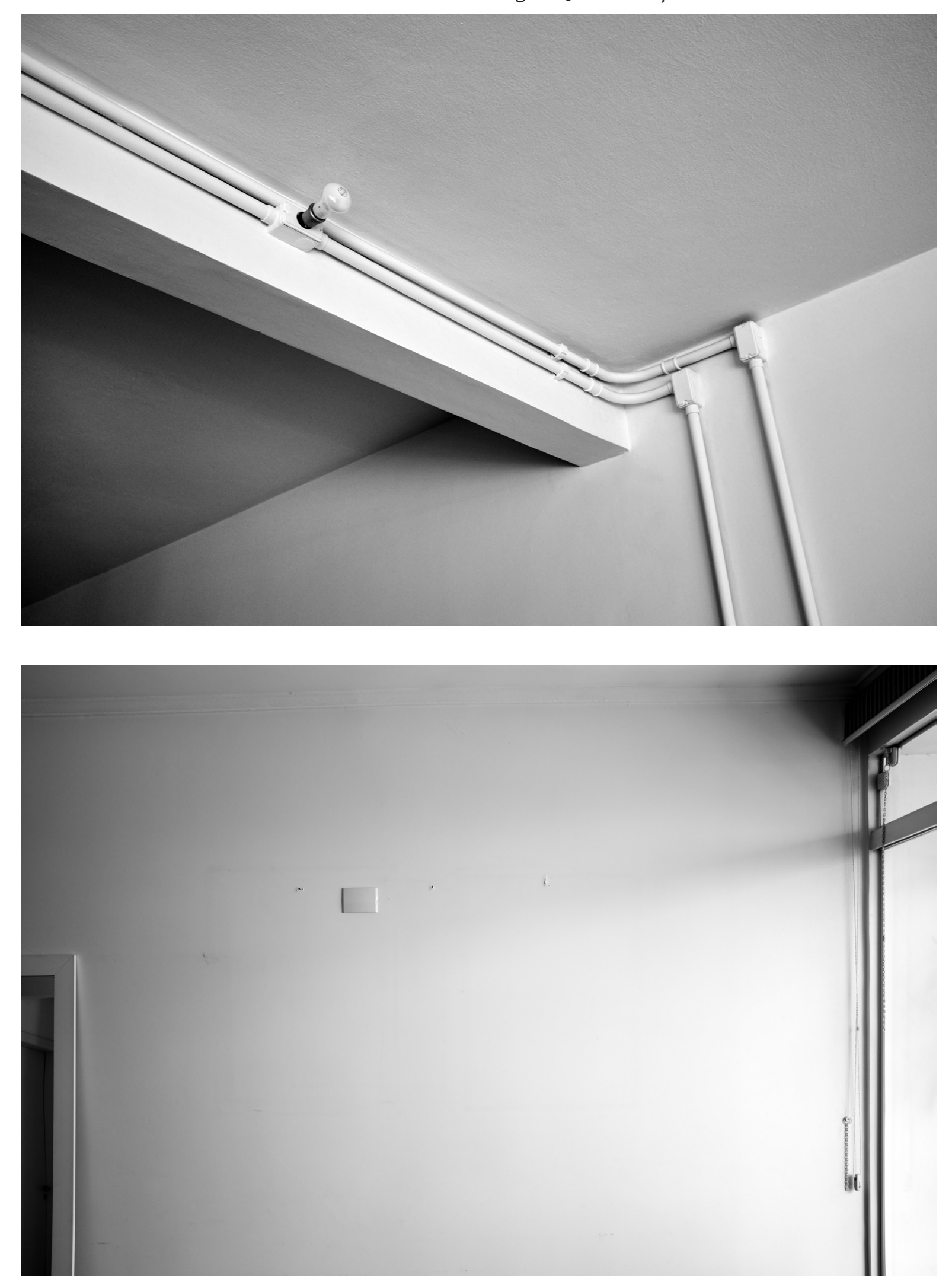